\title{
Science Diplomacy and the Making of the United Nations International Decade for Natural Disaster Reduction
}

\author{
Lukas Schemper \\ Rachel Carson Center for Environment and Society - LMU, Munich \\ lukas.schemper@graduateinstitute.ch
}

\begin{abstract}
The article discusses the creation of the International Decade for Natural Disaster Reduction (IDND R, 1990-1999), a global observance event that emanated neither from within the United Nations - for whom until then disaster management or rights of disaster victims had not been a real priority - nor from within civil society organizations or governments. In actuality, it was primarily a scientist-led initiative. This article suggests that this episode is a rare example of a joint effort on the part of a scientific community to create international scientific institutions to deal with the issue of disaster risk. The framing of the issue as "scientific" by earth scientists led the UN Secretariat and governments to embrace an issue that they had hitherto neglected. However, archival evidence also suggests that the eventual takeover of the project by the UN bureaucracy weakened the role of earth scientists in the IDNDR and changed its orientation.
\end{abstract}

\section{Keywords}

natural disaster - disaster-risk reduction - disaster prevention - UN Decade for Natural Disaster Reduction (IDNDR) - UN global observance - United Nations - Frank Press 
"Natural"2 disasters result in substantial human and economic costs to the world. According to a recent study published jointly by the United Nations International Strategy for Disaster Reduction (UNISDR) and the Centre for Research on the Epidemiology of Disasters (CRED), between 1998 and 2017 natural disasters were responsible for an estimated 1.3 million deaths. They further negatively impacted the lives of 4.4 billion people by either causing injury, or forcing them from their homes, displacing them, or leaving them in need of emergency assistance. Over the same time span, they caused further economic losses of US\$2.245 billion. Recently, major disasters in the United States such as hurricanes Katrina, Maria or Irma, have brought "natural" disaster into the media spotlight. Indeed, over the past twenty years, the UsA has suffered the biggest losses, especially in terms of climate-related disasters (US\$ 944.8 billion). However, relative to countries' GDPs, low-income countries in the Global South have been worse hit, ${ }^{3}$ demonstrating that disasters are not only a problem related to development, but also that vulnerability to disaster has socio-economic or political causes. Over the past decades, two main trends have emerged. On the one hand, the number of people affected by the negative consequences of "natural" disaster is rising. The reasons for this upsurge range from increased vulnerability through urbanization to population growth, growing dependence on technology, or climate change. On the other hand, fewer people are being killed by disasters because humans have been able to better adapt to the risks that hazards create. This adaption includes technical advances, enhanced preparedness, and improved international cooperation. ${ }^{4}$

1 The author wishes to thank the organizers and participants of the conference "'Calendar Propaganda' of Human Rights? Historical Perspectives on the United Nations' Global Observances" at Leiden University (2017) and the panel "The Diplomacy of UN Global Observances" at the Third Conference of the New Diplomatic History Network (2018) at the Roosevelt Institute for American Studies in Middelburg for their feedback on earlier versions of this article. Dr. Anca Cretu also provided useful comments. I am also indebted to the three anonymous reviewers for their constructive criticism and suggestions.

2 The term "natural disaster" generally has to be used with caution as it implies that disasters occur beyond human responsibility. However, most of them happen because people have been rendered vulnerable by political or socio-economic factors. Hence, the word "natural" is placed in quotation marks.

3 Unisdr and Cred. Economic Losses, Poverty and Disasters 1998-2017. (Brussels/Geneva: UNISDR/CRED, 2018).

4 Coppola, D. P. Introduction to International Disaster Management (Boston: Butterworth Heinemann, 2007), 27-38. 
Yet for reasons relating to differing diplomatic strategies, approaches to disaster management, or bureaucratic agendas, governments and international organizations have been slow to put disaster on the agenda of international organizations. Throughout the twentieth century and up until the present day, multilateral mechanisms and international law to address the problem of disaster have considerably lagged behind other areas, such as armed conflict or environmental protection. ${ }^{5}$ In particular, pre-disaster action (such as research, planning, training, establishment of warning systems) has rarely been a political priority of governments. ${ }^{6}$ An OCHA report from 2014 showed that prevention and preparedness funding comprised less than $0.5 \%$ of all international aid of the previous twenty years. ${ }^{7}$ This neglect occurs in spite of the accepted maxim that a considerable part of the costs of ex post relief and reconstruction activities could be avoided if states would be willing to invest more in ex ante disaster prevention and preparedness activities. Also in 2014, the Australian Business Roundtable released a Deloitte-commissioned report on Australia arguing "better risk management and preventative actions could save up to $\$ 14.6$ billion a year in recovery costs following natural disasters." ${ }^{8}$ Yet for the better part of the twentieth century, governments lacked the political will to spend money on multilateral mechanisms that would deal with future threats that were neither visible nor tangible or to prepare against future damages whose risks were difficult to calculate.

One may argue that the obstacle of uncertainty regarding future risk should not necessarily prevent the creation of intergovernmental mechanisms, as this has not prevented governments from tackling equally unpredictable policy

5 Hannigan, J. A. Disasters without Borders: The International Politics of Natural Disasters (Cambridge: Polity Press, 2012); Schemper, L. "La prévention des catastrophes naturelles et les organisations internationales du temps de la sdn au lendemain de la guerre froide. Quelle place pour l'environnement ?" Revue Études internationales 47 (1) (2016), 29-80.

6 Hutchinson, J.F. "Disasters and the International Order: Earthquakes, Humanitarians, and the Ciraolo Project." The International History Review 22 (1) (2000), 1-36; Hutchinson, J. F. “Disasters and the International Order - II: The International Relief Union." The International History Review 23 (2) (2001), 253-98; Schemper, L. Humanity Unprepared - International Organization and the Management of Natural Disaster 1921-1991, PhD Thesis (Department of International History, Graduate Institute of International and Development Studies, 2016).

7 oc HA. Saving Lives Today and Tomorrow: Managing the Risk of Humanitarian Crises (Geneva/ New York: OC HA, 2014).

8 Fielding, Z. "Natural Disaster Preventive Action and Risk Management Could Save over \$14 Billion a Year." Property Observer July 21, 2014, http://www.propertyobserver.com.au/ financing/33589-natural-disaster-preventive-action-and-risk-management-could-save-over -14-billion-a-year.html (accessed October 2, 2018). 
issues in a multilateral way. Today, the "prediction of the unpredictable" is, for example, at the heart of international environmental and security governance. ${ }^{9}$ Entities such as the North Atlantic Treaty Organization (NATO) or the Intergovernmental Panel on Climate Change (IPCC) deal with it on a daily basis, in the sphere of transatlantic security and the economic and political impact of climate change, respectively. Historically, in the governance of uncertainty and in the emergence of international governance mechanisms, more generally, experts and scientists have played an important role. ${ }^{10}$ For instance, regarding the issue of atmospheric ozone depletion or the issue of global warming, experts have been crucial in the creation of international frameworks. Respectively, scientists contributed to the creation of the Montreal protocol (1987), which protects the ozone layer by banning the use of chlorofluorocarbons, and they are an integral component of the peer-review-based approach of the IPCC, which proved that climate change was indeed caused by greenhouse gases. ${ }^{11}$ However, in the sphere of "natural" disaster, international frameworks and other mechanisms have often remained underdeveloped. Authorities may have a tendency to downplay their own responsibility in rendering populations vulnerable to disaster and often lack political will to prioritize funding for disaster-risk-reduction measures. Nevertheless, in contrast to experts on issues such as climate change or tobacco use, disaster experts usually do not face organized campaigns to discredit them. ${ }^{12}$ The reasons for the absence of strong international mechanisms in the field of disaster have to be found elsewhere. One convincing argument is that those dealing with pre-disaster activity - researchers, academics, engineers, and experts - do not organize themselves sufficiently to push for global frameworks and measures. There is indeed a striking lack of a coherent and functional epistemic community of disaster experts that could advance, through states, the implementation of intergovernmental disaster-management treaties and norms. ${ }^{13}$ An important

Vanderlinden, J.-P. “Prévoir l'imprévu.” In L'enjeu mondial: l'environnement, ed. F. Gemenne (Paris: Presses de Sciences Po, 2015), 241-50.

10 Mazower, M. Governing the World: The History of an Idea (London: Allen Lane, 2012), 95.

11 Oreskes, N., and Conway, E. M. Merchants of Doubt: How a Handful of Scientists Obscured the Truth on Issues from Tobacco Smoke to Global Warming (London: Bloomsbury, 2012); Hannigan, Disasters without Borders, 32.

12 Oreskes and Conway, Merchants of Doubt, 3 .

13 Hannigan, Disasters without Borders, 4. The term "epistemic community" has been coined by Peter Haas and means a "network of professionals with recognized expertise and competence in a particular domain and an authoritative claim to policy-relevant knowledge within that domain or issue area." Haas, P. M. "Introduction: Epistemic Communities and International Policy Coordination." International Organization 46 (1) (1992), 1-35, 3. 
reason is the fragmentation not only of the sphere of those who constitute the actors of the "world of natural disasters"14 (such as humanitarian and development organizations, insurance companies, state ministries, scientific bodies) but also of the study of disaster. Typical fields of expertise range from emergency planning to seismology, hydrology, entomology, or the social sciences. This makes it difficult to identify clear and common priorities in the field of disaster-risk reduction.

One rare exception to this lack of organized lobbying by disaster experts for the creation of international institutions for the governance of disaster was the initiative by a network of earth scientists in the early 1980 s to work towards having the 1990s declared the International Decade for Natural Disaster Reduction (IDNDR, henceforth called "the Decade"). The Decade culminated, in 1999, in the creation of a new permanent office of the UN Secretariat, the UN International Strategy for Disaster Reduction (UNISDR), and was the beginning of a still on-going succession of non-binding frameworks through which governments pledge to reduce disaster risk in their respective countries. However, this article is not concerned with the successes and failures of the Decade. Indeed, from a historical standpoint, it might be too soon to judge its legacy. On the one hand, within the UN system, the Decade significantly spurred and stimulated disaster-management activity by relevant entities. At its conclusion, it also led to the creation of a permanent office, which puts disaster in the spotlight and coordinates the international strategies of disaster-risk reduction. On the other hand, until now, all successive strategies have lacked concrete, identifiably (for example numerical) or realistically attainable objectives to which actors could commit on a global scale..$^{15}$

In contrast, this article is interested in the birth of the project for the Decade and the role that scientists played in the diplomacy leading to its creation. Furthermore, it investigates what it meant for actors with a stake in the Decade, such as governments and intergovernmental organizations. Hitherto un-researched holdings in the UN archives in Geneva and New York as well

14 Anthropologist Sandrine Revet employs this term to comprise the "actors, representations of disasters, languages, temporalities, locations, convictions dreams and instruments" relating to disaster. This term is in turn inspired by sociologist Anselm Strauss's (social world) and Howard Becker's (world of art) use of the word. Revet, S. Dans les coulisses du monde des catastrophes «naturelles » (Paris: Maison des Sciences de l'Homme, 2018), 13-14.

15 Prior, T., and F. Roth. "Global Disaster Politics Post Sendai." css Analyses in Security Policy 173 (2015), 1-4. 
as French Foreign Ministry archives from the 1980 s have been consulted here. These archives shed light on international organisations both as diplomatic actors with their own agendas and places of diplomatic activity that are being used by untraditional diplomatic actors to raise awareness of diplomats and their governments for certain policy issues. Correspondence in these archives has been particularly helpful in identifying these actors and issues, their transnational or international networks, and their contributions to the establishment of the Decade. The article thus follows a "New Diplomatic History" approach in as much as it defines as a diplomatic actor not only professional diplomats and foreign ministries, but also international and scientific organisations, as well as scientists and experts. ${ }^{16}$

Moreover, this article suggests that, through the establishment of the IDNDR, scientists managed to put disaster-risk reduction on the agenda of the UN, something that previous initiatives had not managed to achieve. Archives also provide evidence that, while there was disagreement about the exact organization and bureaucracy of the IDNDR, the usefulness of a global observance per se was not questioned by the scientists. This shows that they saw global observances as a useful institution to promote issues of disaster-risk reduction, to create common objectives and synergies, and to encourage and enable cooperation in this field.

To explain the wide acceptance of the idea of the IDNDR, this article emphasizes the role of science and expertise in the making of this global observance. It is thus also an example of the role that scientists and experts may play in diplomacy more generally. They played a crucial role in the diplomatic processes surrounding the creation of the Decade with the objective to increase worldwide support for improved international cooperation in disaster reduction. The "diplomaticity"17 of these scientific actors derives from the fact that when global common goods are at risk, they may have the authority to raise awareness of these risks and provide the technical and specialized knowledge to develop solutions for the future. ${ }^{18}$ To advance this goal, the UN system offers an institutional framework and infrastructures for standardization, collection of data and modelling of future scenarios. In this process of what

16 Scott-Smith, G., and Weisbrode, K. "Editorial." Diplomatica 1 (1) (2019), 1-4, 2.

17 The capacity of a non-diplomatic actor to assume diplomatic functions. Badel, L. "Diplomacy and the History of International Relations: Redefining a Conflictual Relationship." Diplomatica 1 (1) (2019), 33-39, 39.

18 Tenzer, N. "L'expertise internationale." In Traité de relations internationales, eds. T. Balzacq and F. Ramel (Paris: Presses de Sciences Po, 2013), 1169-82; Ruffini, P.-B. Science and Diplomacy: A New Dimension of International Relations (Berlin: Springer, 2017), 106. 
Paul N. Edwards has termed "global environmental surveillance,"19 there exists a pattern, according to which, since at least the 1970s, scientists, emboldened by the new power of computerized modelling, launched warnings and called for action by using UN agencies, NGOS, or international scientific institutions. The 1988 Montreal Protocol on the ozone layer is the most prominent example. In the case discussed here, too, a transnational network of scientists pushed for international awareness and the creation of an international institution. The network could make use of recognized and policy-relevant knowledge on disaster and shared beliefs about the causes of disasters as well as a common technical- and hazard-based understanding of how to address them. The above-mentioned concept of "epistemic community" is thus fitting. However, the community's impact was ephemeral. While it played an important role in the founding of the global observance, it soon lost control both over orientation and institutional design as it was taken over by the UN.

It has been argued that it was the end of the Cold War and the emergence of a more holistic approach to security - which included "natural" disasters - that facilitated the establishment of IDNDR. ${ }^{20}$ However, the preparation of the Decade had started well before the end of the Cold War. It was brought to the table in 1984 by Frank Press at the $8^{\text {th }}$ International Congress of Earthquake Engineering in San Francisco in a keynote address to the International Association of Earthquake Engineering (IAEE). ${ }^{21}$ Much of the success in establishing the Decade can be attributed to Press's standing in the scientific world, his global vision of scientific cooperation, and his professional and political connections. Press was an American geo-physician and from 1981 to 1993 president of the US National Academy of Sciences under both the Reagan and George H.W. Bush administrations. Born in 1924, he had already a long and respected career behind him that had connected him to international and political networks. He became director of the seismological laboratory of the California Institute of Technology in 1955 and recognized early that the military confrontation of the Cold War provided an opportunity to foster the growth of the earth sciences.

19 Edwards, Paul N. "Gouverner le système terre." In Le siècle des technosciences, ed. Dominique Pestre and Christophe Bonneuil, vol. 3, Histoire des sciences et des savoirs (Paris: Éditions du Seuil, 2015), 399-421, 399, 403.

$20 \quad$ Prior and Roth, "Global Disaster Politics." 2.

21 Revet, S. "Les organisations internationales et la gestion des risques et des catastrophes naturelles." Les études du ceri 157 (2009), 8. 
He participated in $195^{8}$ in the Geneva expert group and in the Berkner Panel, both of which contributed to formulating the terms of the Partial Nuclear TestBan Treaty (Ртвт) of 1963. As Director of the California Institute of Technology he contributed to the project Vela Uniform, which was a project by the United States Department of Defense to establish methods to monitor compliance with Ртвт, and he was instrumental in the establishment of a global seismological research network consisting of 120 standardized seismic stations in over 60 countries (World-Wide Standard Seismograph Network). He was also involved in another UN global observance, the International Geophysical Year of 1957/58 as member of its Glaciology and Seismology Panel. ${ }^{22}$ The success of the latter in stimulating international scientific cooperation at a time of high Cold War tensions might have inspired Press in his idea for another, even more ambitious, global observance. In the 1970s, a number of particularly devastating seismic events occurred, including the 1976 Guatemala earthquake that cost the lives of 23,000 people. The United States was reminded of its vulnerability to disaster in 1971, when the San Fernando earthquake hit the Los Angeles area leading to the deaths of 65 . In both cases inadequate building practices could be blamed, and the need to invest in technical solutions to prevent these and similar disasters was obvious. Earthquake engineers such as Frank Press believed that these technical solutions could be applied not only to earthquake risk, but also to the prevention of "natural" disaster more generally. ${ }^{23}$ While the thematic scope of the eventual Decade would widen significantly to include different types of disaster-related disciplines, earthquake engineering would continue to occupy a certain place within the Decade to the end.

Press's fundamental idea for the Decade was to mix science and politics. Scientists should engage more with the public in order to educate them as well as by elaborating publicly applicable measures of their research, such as nationally adapted building codes, insurance plans and emergency plans. ${ }^{24}$ But why use a UN global observance to achieve this objective? The idea of global observances emerged with the realization on the part of UN officials that certain social or humanitarian works would require long-term commitments and that they should be addressed in periods ranging from days to decades. While

22 Barth, K.-H. "The Politics of Seismology: Nuclear Testing, Arms Control, and the Transformation of a Discipline." Social Studies of Science 33 (5) (2003), 743-81, 725; Revet. "Les coulisses," 45 .

23 Hannigan, Disasters without Borders, 62.

24 Press. Discours principal: le rôle de la science et de l'ingénierie pour tempérer les périls naturels. $8^{\text {ème }}$ Conférence Mondiale du Génie Sismique, July 23, 1984, French Foreign Ministry/Ministère des Affaires Etrangères (hereafter MAE), Permanent Representation of France to the United Nations (hereafter ONU Rep.), United Nations in Geneva (UNOG) ${ }_{11} \mathrm{POI} / 1403$. 
days had a commemorative or publicity character, years and decades served the purpose of raising awareness on a large scale (including on the grass-roots level) and of launching or coordinating support for a pressing cause. They demonstrate that governments and UN organizations recognize these issues as crucial and that they need to be prioritized.

Throughout the history of the UN, some Decades had been more successful than others. For example, the UN's Water Supply and Sanitation Decade (1981-91), which was on-going when Press made his proposal, was credited with successfully tackling this issue in Latin America and some African countries. ${ }^{25}$ Other decades have been considered by contemporary observers as failures, such as the first UN Decade of Development $(1960-70)$, which did not achieve the objective of improving the economic performance of developing countries. ${ }^{26}$ Nevertheless, this and other decades raised important expectations of governments, especially from the Global North, to take concrete actions to address the respective issues. Probably aware of the public relations effect of a global Decade, Press similarly wanted to appeal to governments and to a wider audience to increase their commitments to disaster reduction. He firmly believed that it was the state's responsibility to be prepared for the eventuality of a "natural" disaster, but also emphasized the role of scientists in assisting the state to the best of their abilities.

The above reasons explain why Press did not propose a new UN program or organization to deal with disaster, but a global observance. Moreover, by emphasizing the role of the scientist, it can be assumed that Press and his supporters also were hoping to reap some benefits. The Decade would certainly augment the visibility of their research and the propagation of their ideas, not only among fellow scientists, but also among practitioners and international civil servants and government officials. It would professionalize and legitimize their scientific field. ${ }^{27}$ Finally, the idea would not have escaped Press and his supporters that this global raising of awareness of disaster risk would also be an opportunity to raise funds for research in the earth sciences. And indeed, among the international scientific community, the idea received a considerably positive response. ${ }^{28}$

25 Ostrower, G.B. "United Nations (UN) Decades and Years." In The Palgrave Dictionary of Transnational History, eds. A. Iriye and P.-Y. Saunier (New York: Palgrave Macmillan, 2009), 1066-67.

26 Normand, R., and S. Zaidi. Human Rights at the UN: The Political History of Universal Justice (Bloomington: Indiana University Press, 2008), 295-98.

27 On the reasons why scientists decide to join professional associations see for example: Blume, S.B. Toward a Political Sociology of Science (New York: Free Press, 1974), 114.

28 By scientific associations such as the Wind Energy Engineering Research Council, the International Association for Earthquake Engineering, the International Programme of the 
But first, the idea was further developed at the national level. A National Research Council Advisory Committee for the Decade was formed under the chairmanship of George Housner - like Press another renowned professor of Earthquake Engineering at the California Institute of Technology - to evaluate the potential of the project and to elaborate how it might be put into practice. ${ }^{29} \mathrm{~A}$ report compiled by the committee described several possibilities of hazard and risk assessment, prevention and disaster mitigation, and it was meant as a pamphlet to introduce the idea to a wider audience on national and international levels. The report was approved by the Governing Board of the National Research Council, whose members are drawn from the councils of the National Academy of Sciences, the National Academy of Engineering, and the Institute of Medicine (and thus had the legitimation of venerable institutions representing US science). ${ }^{30}$ The report concluded, in line with Frank Press's 1984 speech, that "now" scientific and technological advances in hazard mitigation provided "the means to reduce significantly losses from natural hazards."31 The "now" was justified by the accentuation of unprecedented phenomena in the eyes of the report: hazards were increasing due to "population growth and concentration in urban areas; increasing capital investment coupled with new, sometimes vulnerable technologies; the large number of unsafe buildings, vulnerable critical facilities, and fragile lifelines; and the increasing interdependence of people in local, national and international communities." One can see that the report emphasized the idea that hazards are aggravated by human activity.

One should not forget that around the same time sociologist Ulrich Beck would coin the term "risk society."32 The great technological catastrophes of the 1970s and 1980s (such as the nuclear accident on Three Mile Island in the United States in 1979, the explosion of a pesticide factory in Bhopal in India in 1984 and, ultimately, the nuclear accident at Chernobyl in 1986) were seen by Beck and other sociologists as proof that the trust of society in progress and

Lithosphere of the International Council of Scientific Unions, the International Union of Geological Sciences and the International Association of Applied Geology. Likewise, a dozen national bodies such as the Council of Sciences of Japan, the Royal Society of Canada, the Association of Structural Engineers in Argentina, and the Institute of Engineers of Thailand also expressed their support. Décennie Internationale de la Réduction des Catastrophes Naturelles, June 1987, MAE ONU Rep. UNOG 11POI/1 403.

29 Rattien to Du Cauze de Nazelle, August 11, 1987, MAE ONU Rep. UnOG 11POI/1 403.

30 Report. Confronting Natural Disasters, 1987, MAE ONU Rep. UNOG 11POI/1 403.

31 Rattien to Du Cauze de Nazelle, August 11, 1987, MAE ONU Rep. UNOG 11POI/1 403.

32 Beck, U. Risikogesellschaft: auf dem Weg in eine andere Moderne (Frankfurt am Main: Suhrkamp, 1986). 
science inherited from the enlightenment was broken. For Beck, these types of disaster were evidence of the start of what some may call the "society of risk," which stipulated that a society produces its own risks to such a degree that they become part of how a society measures itself. The causes of risk menacing a society no longer come from outside, but instead from inside. Interestingly, a constitutive element of the risk society is that society loses faith in the capacity of experts to shield them from disaster. As risk becomes the new normal, they produce increasingly unintelligible information as explanation for why disasters happen. ${ }^{33}$ While historians have recently questioned the unprecedented nature of said "risk society" in modern times, the view that confidence in scientific expertise to manage risks was waning was prevalent in the 1980 s. $^{34} \mathrm{Read}$ in that way, Frank Press's project can be seen as an attempt to regain the public's faith in the ability of science to manage risk, even if his focus was on risk stemming from natural hazards.

While Press did not necessarily envisage the Decade to be branded as a "UN decade" or to be managed by the UN, he knew that he would need a wide and global forum with access to governments to promote his ideas. As president of the US Academy of Sciences, he was in a position to start the lobbying at the top. He approached the UN Secretary-General Pérez de Cuéllar for the first time in mid-April 1987 and seemed to have easily sparked the Secretary-General's interest in the matter, ${ }^{35}$ as the latter expressed his "enthusiasm" for the project not only for scientific reasons. ${ }^{36}$ The UN Secretariat had initially hoped to limit the number of official observances so as not to dilute their importance, ${ }^{37}$ but in this case, Pérez de Cuéllar believed that the Decade would be a concrete project that could have a favorable impact on public opinion about the UN, especially in the United States. As de Cuéllar would later recall, he was deeply

33 Walter, F. Catastrophes: une histoire culturelle: XVIe-XXIe siècle (Paris: Éditions du Seuil, 2008), ch. 9 .

34 Itzen, P., and Müller, S. M. "Risk as a Category of Analysis for a Social History of the Twentieth Century: An Introduction." Historical Social Research / Historische Sozialforschung 41 (1) (2016), 7-29, 12.

35 Press to Perez de Cuéllar, April 27, 1987, United Nations in New York (hereafter UN NY) Pérez de Cuéllar S-1048-0089-0005 Director-General for Development and International Economic Co-operation (hereafter DIEC) - IDNDR.

36 Siefer-Gaillardin/Chazerand to Raimond, 1987, MAE ONU Rep. UnOG 11POI/1 403.

37 Ostrower, "United Nations (UN)." 
disturbed by the hostile attitude of some American officials during part of his tenure, in particular by the attitudes of the neoconservatives of the Reagan administration, who criticized the UN as being badly administered and inimical to American interests. To counter such opposition, de Cuéllar attached the highest importance to maintaining positive and constructive relations with the United States. ${ }^{38}$ Furthermore, the Secretary-General also regarded the Decade as a chance for strengthening North-South cooperation in a field that was unlikely to be politicized. ${ }^{39}$ Luis M. Gomez, Assistant Secretary-General for Programme Planning, Budget and Finance, noted that although it was necessary to have a General Assembly resolution in order to establish an international decade, it should be "understood that it is an initiation of the international organizations and, therefore, the leading role being ours." He believed that this was "a thunder that should not be stolen from the United Nations" and that the UN "should take a clear and immediate leading role." 40

However, for the United Nations, there was more to this Decade project than simply using it as a publicity stunt. It could be an opportunity to put disasterrisk reduction on the UN's agenda and to close an important thematic gap in the UN system. The 1980 s were a decade, in which a number of unprecedented or large-scale "natural" disasters happened, including the 1983-85 droughts and famine in Ethiopia or the 1988 Armenia earthquake. Yet no credible international institution or mechanism existed to promote disaster reduction on a global scale. Certainly, the topic of disaster touched on the work of different actors of the UN system such as UNESCO, WMO, UNDP, WHO or UNEP, but it had never been a particular focus of their work. Organizations focused on particular aspects of disaster prevention and preparedness (scientific, health, humanitarian, environment) rather than on different types of disaster and phases of disaster management in their entirety. Problems of coordination were frequent, and some of these organizations saw disaster as a nuisance hindering development rather than an opportunity promoting it. ${ }^{41}$

38 Franda, Marcus F., The United Nations in the Twenty-First Century: Management and Reform Processes in a Troubled Organization (Lanham: Rowman \& Littlefield Publishers, 2006), 61. The number of people in the United States who thought the United Nations was doing a poor job was increasing over the 1980s, according to Gallup polls. Roper Center for Public Opinion Research. "Seventy Years of U.S. Public Opinion on the United Nations" (June 22, 2015), https://ropercenter.cornell.edu/blog/seventy-years-us-public-opinionunited-nations (accessed May 20, 2019).

39 De Nazelle to French foreign minister, July 16, 1987, MAE ONU Rep. UNOG 11POI/1 403.

40 Gomez to de Soto, June 12, 1987, UN NY Pérez de Cuéllar S-1048-0089-0005 DIEC - IDNDR.

41 Schemper, "La prévention des catastrophes naturelles," 29-80. 
This lack of international institutions or frameworks to deal with disasterrisk reduction persisted in spite of a variety of historical attempts to create such institutions going back to the inter-war period. When the International Relief Union, an intergovernmental humanitarian organization with institutional links to the League of Nations and the Red Cross movement was created at an international conference in Geneva in 1927, its convention stated that it would not only coordinate international disaster relief, but also "encourage the study of preventive measures against disasters" (art. 2 par. 2). In order to furnish local information on disaster as well as to lobby governments for the creation of the International Relief Union, national study commissions were established in several countries. Its members, mostly earth scientists, contributed to an international journal of "disaster studies" avant la lettre and also convened at the "Conférence internationale pour la protection contre les calamités naturelles" in 1937 in Paris. However, this first epistemic community of disaster proved to be ephemeral, as it disintegrated during the Second World War simultaneously with the International Relief Union. The international historical context of rising nationalism, economic crisis and, ultimately, global war was not conducive to a transnational or multilateral approach to dealing with "natural" disaster. ${ }^{42}$

In the first twenty-five years following the Second World War, disaster continued to be neglected at the United Nations. No institution existed at the United Nations to deal with disaster relief. The focus of governments and humanitarian organizations was at first the reconstruction of Europe, followed by the provision of development to what was then referred to as the Third World. Most governments objected to supranational or multilateral forms of relief, as they realized the potential of bilateral aid for their foreign policies, in particular in the Cold War context. ${ }^{43}$ UNESCO was until the 1970 s the only UN

42 The International Relief Union officially existed until 1981, but neither managed to be integrated into the United Nations system nor to carry out any meaningful activity on its own after the Second World War. Davey, E. A History of the Humanitarian System: Western Origins and Foundations (London: Overseas Development Institute/Humanitarian Policy Group, 2013), 30. Schemper L. "Transnational Expertise on Natural Disasters and International Organizations: Historical Perspectives from the Interwar Period." In Transnational Expertise, eds. C. Henrich-Franke et al. (Baden-Baden: Nomos, 2018), 29-54.

43 See for example Forsythe, D.P. "Humanitarian Assistance in U.S. Foreign Policy, 1947-1987." In The Moral Nation: Humanitarianism and U.S. Foreign Policy Today, eds. J. B. Nichols and G. Loescher (Notre Dame: University of Notre Dame Press, 1989), 63-90, 73; Pordes, R. "The Funding of International Relief Assistance in Disaster Situations." In Disaster Assistance: Appraisal, Reform \& New Approaches, eds. L. H. Stephens and S. J. Green (New York: Macmillan Press, 1979), 49-82, 6o; Langeais, G. Les Nations Unies face aux catastrophes naturelles: étude du Bureau du coordonnateur des Nations Unies pour les secours en cas 
organization to reflect on questions of disaster-risk reduction, for example, in the 1960s, through the organization of seismological missions and its involvement in the creation of a tsunami alert system in the Pacific. Over the decades, UNESCO expanded its activities in disaster reduction significantly, including other types of catastrophes such as volcanic eruptions, landslides, or flooding. However, in the mid-1980s, it still did not have its own program on disaster and did not serve as a focal point for disaster reduction at the United Nations. ${ }^{44}$ Only in 1971 was the UN Disaster Relief Office (UNDRO) created to coordinate the disaster-management activities of UN agencies, NGOs and governments, but this office also failed to establish itself as a leader in disaster-related matters. It had been created in the face of several particularly devastating catastrophes, such as the earthquake in Peru in May 1970 and the cyclone Bhola that devastated East Pakistan in the fall of the same year. It can also be seen as a response to demands by newly decolonized states that the UN assume a larger role in this domain. ${ }^{45}$ However, its approach was one of top-down, ex-post disaster relief. It also had the ambition to develop a wider "International strategy for disaster prevention" to be ready for 1977. An international group of experts, chosen by UNDRO and in consultation with interested governments and organizations, should formulate an international long-term strategy for the prevention of catastrophes. ${ }^{46}$ However, due to lack of funding and internal divisions at the United Nations, this and similar projects never left the planning stage.

The UN Secretariat's support of Press's scientist initiative a decade later can thus be interpreted as a renewed willingness to return this issue to the UN's agenda. The UN Secretary-General told Press to proceed and advised him to approach governments through the National Research Council in view of a General Assembly resolution. ${ }^{47}$ Although it was not yet clear what UN agency would be responsible for dealing with affairs relating to the Decade, the UN as an important stakeholder had been convinced to support the project. However, ambitious projects for global governance usually materialize only if they

de catastrophe (Paris: Librairie générale de droit et de jurisprudence, 1977), 5; Note. G. de Chambrun 1965, MAE C NUOI 1960-1961, 646, S3-16 UIs.

44 Fournier d'Albe to Waldheim, June 2, 1981, UN NY Waldheim S-og11-0o04-04 UNDro.

45 Kent, R. C. Anatomy of Disaster Relief: The International Network in Action (London: Pinter, 1987), 51; Revet, "Les organisations internationales." 6.

$46 \mathrm{UN} \mathrm{AG} 30^{\text {th }}$ session. Plan à moyen terme pour la période $1976-1979$, Supplément $\mathrm{N}^{\circ} 6 \mathrm{~A}$ (A/10006/ADD.1). UneSCo SC/geo/5350.

47 De Cuéllar to Press, June 23, 1987, UN NY Pérez de Cuéllar S-1048-0089-0oo5 DIEC IDNDR. 
are supported by states. Hence, Press and his supporters needed to start lobbying state governments next.

\section{$4 \quad$ Winning over States}

The tasks now were to find a handful of states to co-author a resolution to be submitted to the General Assembly, to organize a conference before 1990 and to officially launch the Decade in the same year. The lobbying was accomplished in particular by Frank Press's collaborators Stephen Rattien of the US National Research Council (Deputy Executive Director - Commission on Engineering and Technical Systems), Mitchell B. Wallerstein from the US National Academy of Sciences and André Varchaver (US Diplomat and Consultant at the National Academy of Sciences). They met with foreign diplomats in the United States in hopes of convincing them of the utility of the Decade. ${ }^{48}$

Eventually, GA res. A/42/169 was presented by Morocco with France and Japan as the only Western co-sponsors on December 11, 1987,49 signifying the priority status of this issue, in particular, for the non-Western part of the world. The resolution provided the first institutional framework for the Decade. It emphasized the need for national, regional and worldwide programs and the requirement to "take into account the cultural and economic diversity among nations." Following an approach similar to that of the International Relief Union of the inter-war period, it called on participating governments "to establish national committees, in co-operation with the relevant scientific and technological communities, with a view to surveying available mechanisms and facilities for the reduction of natural hazards" and to "improve or update existing mechanisms and facilities." ${ }^{.50}$

Once the UN resolution had been adopted, the UN Secretary-General designated Jean Ripert, Director-General for Development and International Economic Cooperation, as his representative for the Decade. He also created an inter-agency steering committee for the Decade, which assisted the Secretary-General in outlining measures to be presented to the UN General Assembly's $43^{\text {rd }}$ and $44^{\text {th }}$ sessions and which was tasked with working out the administrative details. This advisory body was composed of representatives of

48 Siefer-Gaillardin/Patrice Chazerand to Raimon, 1987, MAE ONU Rep. UNOG 11POI/1 403; DIRCN, MAE ONU Rep. UNOG $11 \mathrm{POI} / 1403$.

49 Levitte to Ministre des Affaires Etrangères, May 31, 1988, MAE ONU Rep. UNOG 11POI/1 404.

50 GA A/RES/42/169, February 25, 1988, UN NY S-1048-0048-0005 DIEC - IDNDR. 
international organizations and academia. ${ }^{51}$ The measures proposed by the UN steering committee comprised, most importantly, the creation of an international preparatory group of experts that was charged with helping the Secretary-General to plan and prepare the Decade and to assist in finding a thematic orientation. Here, the National Academy of Science in Washington once again played an important role. On behalf of Ripert it invited experts from mostly earth sciences from around the world to attend an informal meeting with senior UN officials (of the steering committee) on March 22, 1988 to recommend specific objectives for the Decade. ${ }^{52}$ Furthermore, a small provisional secretariat, associated with the UN disaster relief organization UNDRO, was put into place and charged with organizing the meetings of the preparatory group, of the expert committee, and the inter-institutional working group of the UN. It was to assume within the UN system the functions of an information and liaison center regarding the preparation of the Decade. ${ }^{53}$

The ad-hoc expert group convened four times in 1988 and 1989, at the UN Headquarters in Geneva, ${ }^{54}$ in New York as well as in Rabat and finally in Tokyo in April 1989. ${ }^{55}$ During the last meeting a final declaration was drafted, which expressed to the world their "common conviction that millions of lives can be saved, hundreds of millions protected from tragedy, and hundreds of billions of dollars saved as a result of the International Decade." ${ }^{56}$ However, disagreement arose within the expert group concerning the question of whether the secretariat of the Decade should be within or outside the United Nations. Perhaps Press already had a foreshadowing that he and his network of scientists would lose influence over the Decade after a UN takeover, as he favored an institutional arrangement independent from the UN. However, a slight majority of 13 (out of 25) participants supported having the secretariat within the UN system. ${ }^{57}$ The alternative idea that the Decade Secretariat should not necessarily be part of the United Nations and could be financed by banks and insurance companies was also received with scepticism by states. Not only had UN organizations such as the Secretariat, UNESCO, WMO and UNDRO already

51 Press Release. February 19, 1988, UN NY S-1048-0048-0005 DIEC - IDNDR.

52 Draft terms of reference and structure of the ad hoc international group of experts to plan for the IDNDR, May 1988, UN NY S-1048-0048-0005 DIEC - IDNDR.

53 Aveline to Mercier, October 11, 1988, MAE ONU Rep. UNOG 11POI/1 404.

54 UN Press Release. Secretary-General established International Ad Hoc Experts Group for IDNDR, June 28, 1988, MAE ONU Rep. UNOG 11POI/1 404.

55 GA Report by UN SG A/43/723, October 18, 1988.

56 Tokyo Declaration on the IDNDR, April 11, 1989, MAE ONU Rep. UNOG 11POI/1 404.

57 Blanca to Pérez de Cuéllar, April 19, 1989, UN NY S-1048-0066-0005 DIEC - IDNDR. 
manifested their interest in playing a crucial part in the Decade, but it would also be difficult to raise the Decade's budget through the private sector. ${ }^{58}$

Financial considerations did not keep governments from supporting the Decade project at this stage. The resolution that proclaimed the Decade starting on January 1, 1990 and which was brought before the UN General Assembly by the representative of Morocco on December 22, 1989 was accepted with the signature votes of 156 states out of 162 - a rare unanimity. According to Revet, the "scientific" origin of the resolution explains the outstanding support by states, as they considered it an apolitical issue. Through this resolution, the General Assembly adopted what it called the "international framework of Action for the International Decade for Natural Disaster Reduction." It requested the Secretary-General to report on progress at the following UN General Assembly session. ${ }^{59}$ The framework incorporated all suggestions from the Tokyo expert report, but was clear about the fact that the Decade Secretariat should be kept within the UN, attached to UNDRO but independent from it. The decision to separate disaster relief and disaster-risk reduction (the Decade) was going to have fundamental consequences for the approach to international disaster management at the United Nations in the years and decades to come. A trust fund was established by the UN Secretary-General for extra-budgetary resources gained through voluntary contributions to implement the Decade. ${ }^{60}$ Government Agendas

Who would contribute to this fund? More generally, global governance of disaster reveals the more general problem of the governance of commons on a planetary scale as well as the difficulty in predicting future financial resources. As explained in the introduction to this article, this was a problem that continuously plagued the few international mechanisms created to deal with disaster. As far as the Decade was concerned, those states whose present diplomatic agendas coincided with the direction of the Decade were particularly generous in the initial funding phase.

The biggest contributor to the above-mentioned trust fund was Japan. In 1989 and therefore only in the preparatory phase, Japan contributed 652,000

\footnotetext{
58 Blanc to French Mission in NY, May 30, 1989, MAE ONU Rep. UNOG 11POI/1 404.

59 UN GA A/RES/44/236, December 22, 1989.

6o Blanc to Quai d'Orsay, October 20, 1989, MAE ONU Rep. UNOG 11POI/1 405.
} 
USD; followed by the Federal Republic of Germany and Italy, which gave $45^{0,000}$ USD each. ${ }^{61}$ Japan had financed the preparatory expert committee and hosted the Tokyo conference as well as the subsequent world conferences of Yokohama (1994), Kobé (Hyogo) (2005) and Sendai (2015). For the conference of 1994 alone, Japan provided 1.6 million USD. ${ }^{62}$

This steady support was part of a coherent policy. In 1989, Japan was again about to increase its aid to developing countries, making it the world's biggest provider of development aid with $\$ 10 b n$ in $1989 .{ }^{63}$ To finance disaster-risk reduction activities was a logical investment, as it would also benefit Japan, a country that was regularly plagued by disasters such as earthquakes and tsunamis. In a special issue of an UNDRO newsletter devoted to the IDNDR, a New Year's address on the IDNDR by Japan's Prime Minister Toshiki Kaifu was the first contribution. ${ }^{64}$ For Japan, the Decade was a means of gaining visibility in UN affairs, as one UN official noted in $1994 .^{65}$

Other governments were more reluctant with their support, although some of them soon discovered advantages that would be in their own interest. One of these countries was France. When the French were first confronted with the proposal for a decade, the French ambassador to the UN in New York was sceptical regarding the concept of a decade and believed that it had been overused. As the preparations for the Decade took shape, however, French State Secretary for Humanitarian Action, Bernard Kouchner, in particular, realized that the IDNDR could be used to advance the agenda that was most important to him, the droit d'ingérence. In December 1988, France - i.e. Kouchner - had been active to see UN GA resolution 43/131 ("assistance humanitaire en cas de catastrophes naturelles et situations d'urgence du même ordre") adopted. The principle of free access to victims was its most notable element, obliging states to allow transit. ${ }^{66}$ The fact that the Decade was supposed to deal primarily with the mitigation of disaster risk and not intervention in sovereign states did not seem to be of much importance.

Other governments became more active when they were requested to create national committees for the Decade. The national committees were to have six

61 Blanc to Quai d'Orsay, February 22, 1990, MAE ONU Rep. UNOG 11POI/1 405.

62 Hansen to Aimé, March 21, 1994, MAE ONU Rep. UNOG 11POI/1 405.

63 Statement by Mr. Kagami of the Japanese Delegation to the Trieste Workshop on IDNDR Policy Issues and Scientific Priorities, July 1989, MAE ONU Rep. UNOG 11POI/1 404.

64 Kaifu, "Promoting International Co-operation." UNDRO News, January/February 1990, 4.

65 Mourad Wahba. Note to M. Aimé, March 25, 1994, UN NY S-1046-0005-07 IDNDR.

66 Assistance humanitaire aux victimes des catastrophes naturelles et situations d'urgence du même ordre, UN GA 43/131, December 8, 1988. 
main focus areas: the identification of hazard zones and hazard assessment; monitoring, prediction and warning; short-term protective measures and preparedness; long-term prevention measures; land-use and risk management; public education and information. ${ }^{67}$ The United States was the first to create such a committee in 1989, established by the National Research Council and with the collaboration of the US government. This activity should not disguise the slow responsiveness of states to the recommendation to create these committees. As of 1990, only the USA, Germany and Japan had created national commissions. ${ }^{68}$ In the end, the creation of national committees was more successful than the initial turnout would have led us to expect. More than 70 governments had established either national committees or focal points by the end of January 1991, more than 90 by the end of June 1991 and already nearly 100 as of September 1991. However, as a report by the UN Secretary-General emphasized, few of them were "at this stage in a position to function effectively and it [was] obvious that many of them [would] need advice and support."69

\section{A Change of Orientation through the UN Takeover}

The purpose of the Decade Secretariat was to provide support and guidance. However, the takeover of the Decade by the United Nations also brought some important changes to the initial project. The first was a general lack of influence by Press and his supporters on the institutional developments of the Decade. While Press was still crucial in formulating the Tokyo declaration of 1989, he had no say in the hiring of the head of the Decade Secretariat. Press recommended Dr. Michel Lechat for the post, who was also a member of the Experts Group and who had experience in working with the UN. This Belgian epidemiologist had played a key role in advancing the discipline of disaster studies in the francophone world in the 1970s through the creation of the Centre for Research on the Epidemiology of Disasters. ${ }^{70}$ Lechat developed in the 1970 a a cyclical understanding of disaster that includes a relief dimension, but also involves prevention and preparedness as well as a rehabilitation phase. The latter would include an assessment phase that would again prepare for the next

\footnotetext{
67 Report by UN SG to GA, A/43/723, October 18, 1988, MAE ONU Rep. UNOG 11POI/1 403.

68 Quai d'Orsay to French Delegation at Ecosoc, July 5, 1989. Report. Confronting Natural Disasters, 54, 1987, MAE ONU Rep. UNOG 11 POI/1 404.

69 IDNDR, GA A/RES/45/185, 1990, UN NY S-1048-0073-0005 DIEC - IDNDR.

70 La Sablière to Quai d'Orsay, January 19, 1990, MAE ONU Rep. UNOG 11POI/1 405.
} 
disaster. ${ }^{71}$ Such a vision might have brought a more inclusive understanding of disaster management to the United Nations. However, in the end, the UN Secretariat appointed Neelam S. Merani, who was director for Policy Development and External Relations at the UN Environment Programme (UNEP), to the post solely because he had the appropriate rank and was soon to be out of a job within the UN system. ${ }^{72}$ This displeased all major donor governments, including Morocco, USA, Japan, and Italy. ${ }^{73}$ The latter complained that Merani had neither "the necessary professional profile" nor "proper mediating capacity." Merani had been appointed without any consultation with the scientific community and therefore lacked the backing of those who had come up with the entire idea of the Decade. As evidence of the continued importance of scientists in the project, they made it clear that should Merani remain in place the respective governments would stop donating to the Decade, ${ }^{74}$ an opinion that was shared by an increasing number of donors. ${ }^{75}$ Under mounting governmental pressure, Merani was dismissed from his post in May 1991 and replaced by a more suitable candidate, the Finn Dr. Kaarle Olavi Elo, a trained physician and staff member of the World Health Organization. ${ }^{76}$ The bureaucratization and politicization of the staffing decisions is as such not surprising and was a necessary trade-off for Press and his scientific network to gain wider support.

The second and more important consequence of the UN takeover, however, was that the agenda of the Decade became increasingly connected with other UN priorities. In the same way as governments tried to use the Decade for their own agendas, the UN Secretariat also tried to align the Decade with its own interests. This is also not surprising, as the creation of cohesion and coherence among UN actors with relevant work on disaster was even a major purpose of the Decade. But what exactly was it that the UN brought to the table?

The Technical and Scientific Committee, responsible for setting the thematic orientation of the Decade, was in particular involved in linking the Decade with two other interrelated questions high on the agenda of other

\footnotetext{
71 Revet, Dans les coulisses, 37-38.

72 Annan and Gomez to Dayal, March 30, 1990, UN NY S-1048-0073-0005 DIEC - IDNDR.

73 Gomez Note, April 19, 1990, UN NY S-1048-0073-0005 DIEC - IDNDR.

74 Ahtisaari, Notes to the file, October 19 and 24, 1990, UN NY S-1048-0073-0005 DIEC IDNDR.

75 Blanca to Dayal, December 7, 1990, UN NY S-1048-0073-0005 DIEC - IDNDR.

76 Eliasson to Boutros-Ghali, October 12, 1992, UN NY S-1082-0035-05 Department of Humanitarian Affairs (DHA) - IDNDR; A/RES/45/185 on the report of the Second Committee, A/45/848, IDNDR, 1990, UN NY S-1048-0073-0005 DIEC - IDNDR.
} 
United Nations fora at the time: the environment and development. The link between the two issues was for the first time highlighted by the report "Our Common Future" of the World Commission on Environment and Development, the "Brundtland report" named after the commission's chairwoman, the Norwegian Prime Minister Gro Harlem Brundtland. ${ }^{77}$ Environmental issues were interpreted as the result of the protracted poverty of the South and nonsustainable forms of production and consumption in the North. The report emphasized the continued necessity of economic growth, but under the condition of using or expanding environmental resources in a sustainable way. "Growth has no set limits in terms of population or resource use beyond which lies ecological disaster," the report stated. The link with disaster prevention was thus easily established. It warned that during the 1970s, twice as many people were affected each year by "natural" disasters than was the case during the 1960 os and that human activity such as deforestation, over-cultivation or bad urban planning was to blame. ${ }^{78}$

In a certain way, the Brundtland report recognized a reality that developmentoriented disaster researchers had tried to call attention to since the 1970s. This group of researchers was not interested in the hazard per se, but in the social, political and economic conditions that made a society vulnerable to disaster. ${ }^{79}$ For example, geographers Ben Wisner, Phil O'Keefe and Ken Westgate argued in the first issue of the journal Disasters in 1976 that the vulnerability of the Sahel to drought had been the product of the destruction through market capitalism of native environmental knowledge of adaption. ${ }^{80}$ This interpretation of the causes of disaster differed from those promoted by Press and his supporters. By virtue of their scientific and technical orientation, they managed to bring together a network of mainly earth scientists, who hoped that their research would receive more priority.

A drift towards a social and development approach could already be noticed in some of the meetings leading up to the Decade. After the 1989 Tokyo declaration, a follow-up high-level workshop was organized by UNDRO and

77 Reinalda, B. Routledge History of International Organizations: From 1815 to the Present Day (New York: Routledge, 2009), 651.

78 World Commission on Environment and Development. Report of the World Commission on Environment and Development: Our Common Future (United Nations, 1989) (no pagination).

79 Revet, S. "Penser et affronter les désastres : un panorama des recherches en sciences sociales et des politiques internationales." Critique internationale $5^{2}$ (3) (2011), 157-173, 162.

$80 \quad$ Wisner, B., Ph. O'Keefe, and K. Westgate. "Global Systems and Local Disasters: The Untapped Power of Peoples‘ Science." Disasters 1 (1) (1977), 47-57. 
the Institute of International Sociology (ISIG) in Italy. ${ }^{81}$ The workshop aimed at providing IDNDR national committees, UN organizations, and scientists a forum for discussing the concrete implementation of the Decade. Among the sociologists who spoke, ISIG's Dr. Carlo Pelanda challenged the still prevalent view that "natural disaster" was only a physical event and that therefore risk could be reduced simply by "sectoral technical intervention." Besides the direct, physical, "contingent" cause of a disaster, there is also always a "structural," social cause to consider: vulnerability was created by social factors. Therefore, Pelanda argued, the impact of disasters could be reduced by "functionally elaborating the socio-political causes of structural vulnerability to them." The UN, he argued, could play a crucial role here in encouraging national developments that then converge internationally through international agreements. ${ }^{82}$

The idea that the reduction of vulnerability should be key was also shared by the IDNDR secretariat. In a meeting at the Quai d'Orsay three months into the Decade, the provisional Director of the IDNDR Secretariat, Alessi, told his interlocutors that the long-term objective of the IDNDR was that in the future all projects of technical cooperation would include a clause on the reduction of vulnerability, be it in multilateral or bilateral projects. ${ }^{83}$ In line with this conviction, the Decade's Technical and Scientific Committee advised that the United Nations Conference on Environment and Development ("Earth Summit"), which took place in June 1992 in Rio de Janeiro at the recommendation of the Brundtland report, recognize disaster management as "integral parts of national planning for sustainable development." 84 The Scientific and Technical Committee also contributed to the preparations of the Earth summit itself through exchanges with the Secretariat of the Summit and was also represented at the ASCEND'21 (Agenda of Science for Environment and Development into the $21^{\text {st }}$ Century) meeting, which had the purpose of formulating the scientific basis of the summit. It was there that the link between "natural" disaster prevention and sustainable development found its way into Agenda 21, the Rio summit's action plan. ${ }^{85}$

81 DG Blanca to Perez de Cuéllar. April 19, 1989. S-1048-0066-0005 DIEC - IDNDR.

82 Pelanda. The "IDNDR" Systemic Scenario. July 1989, MAE ONU Rep. UnOG 11POI/1 404.

83 Compte-rendu de la réunion du 27 Mars 1990, visite de M. ALEsI, Paris. March 30, 1990, MAE ONU Rep. UNOG 11POI/1 405.

84 First Annual Report of the Scientific and Technical Committee, 1991, UN NY S-1048-00810006 UN Information Centres (UNIC).

85 IDNDR, A/48/219/Add.1 E/1993/97/Add.1, August 23, 1993, UN NY S-1082-0035-05 DHA - IDNDR. 
For the first time, there was thus a coherent joint effort to frame disaster as a poverty and development issue. When the new UN Secretary-General Boutros Boutros-Ghali issued a message on the occasion of the international day for natural disaster reduction in 1992, he also put the focus on sustainable development: "Since the goal of the International Day is 'the reduction of loss of life, property damage and social and economic disruption caused by natural disasters,' the linkage between natural disaster reduction and sustainable development, underscored by the theme, is of special significance to all Decade partners." ${ }^{86}$ This was in stark contrast to the thematic orientation that Press and his supporters had promoted and, which - as mentioned above was hazard-centered. Although there was an awareness of the vulnerability of populations to technically or industrially caused risks, the socio-economic or political underlying causes of disasters had not been central to initial concerns of the Decade project. Consequently, a number of scientists criticized the new orientation of the Decade. George Housner suggested in 1992 that new initiatives should be started only in the earthquake-engineering community, as the Decade did not seem to bear any tangible results. Geographer Terry Cannon denounced the Decade in 1994 saying that it would "betray the strength of the old outlook." 87

On the one hand, this shift meant the recognition of a primordial problem, the socially constructed vulnerability that turns hazards into disasters. On the other hand, the shift also diluted the Decade's initial goals of furthering scientific and technical progress in disaster prevention and preparedness. Earthquake engineers continued to have some influence on the Decade, for example, through a programmatic focus on cities in seismic zones in the last three years of the Decade - but not as much as at the outset. ${ }^{88}$ The dilution did not happen only by broadening the Decade's scientific scope, but also by associating the Decade with the already vague agenda of sustainable development. The objective of "sustainable development" as outlined in the Brundtland report has been judged by development scholar Gilbert Rist as being ill-defined, avoiding the attribution of responsibility, and lacking concrete practical strategies. ${ }^{89} \mathrm{~A}$ similar criticism would in the following decades be formulated towards the disaster-risk reduction strategies of the United Nations. ${ }^{90}$

\footnotetext{
86 UN Press Release SG/SM/4834 ND/369, October 13, 1992.

87 Both are quoted in Hannigan. Disasters without Borders, 66-67.

88 Hannigan, Disasters without Borders, 70.

89 Rist, G. The History of Development : From Western Origins to Global Faith (New York: Zed Books, 2008), 181-185.

90 Prior and Roth, Global Disaster Politics, 1-4.
} 
This article has demonstrated that after decades of failed attempts to raise international attention for the necessity to invest in disaster prevention and preparedness measures, it took an initiative by scientists to firmly put what was then coined disaster-risk reduction on the agenda of the United Nations. This was achieved by declaring the 199os the "Decade for Natural Disaster Reduction." As in the case of previous UN Decades, the format of the "decade" as opposed to days or years, was chosen because its promoters believed that a long-term commitment was required to raise awareness for substantive advances in risk reduction and to launch, support and coordinate this pressing cause on a global scale.

The episode also highlights the importance of individuals and their networks for the creation of international institutions. Frank Press, through his numerous high-level scientific and political appointments since the 1950s, enjoyed sufficient credibility and networks to gather first support among fellow scientists and scientific associations on domestic and international levels, and, in a second step, among the members of the UN Secretariat and governments. His role in establishing IDNDR was instrumental, but - as with the founding myths of other international institutions - the creation of the Decade cannot be attributed to one single individual. The UN Secretariat was keen on supporting the Decade project, believing that it could have a positive impact on public opinion about the UN. It also regarded the Decade as a chance for fostering cooperation between developed and under-developed countries in a field that was deemed scientific, hence politically neutral. Therefore, the UN Secretariat welcomed Press's initiative and counted on Press to bring "with him much of the support of the scientific community."11 But in the end, the UN Secretariat wanted to make it "its own."

Indeed, as this article has illustrated, the support by the Global South for the Decade project is attested by the list of sponsors of the first UN General Assembly resolution, which decided the future institutional framework for the Decade. More generally, the UN General Assembly resolution, which in December 1989 officially launched the Decade, was adopted with sweeping support from all UN member states. While the Decade was once given only lukewarm support by governments, its framing as hazard-centered and scientific in the context of disaster relief detached it from political motives. However, this objective recasting also had the effect of disconnecting the Decade

91 Director ODg/Diec to Chef de Cabinet, June 30, 1989; Blanca to Pérez de Cuéllar, April 19, 1989, UN NY S-1048-0066-0005 DIEC - IDNDR. 
from its humanitarian component, which was entrusted to the successor of UNDRO, the Department of Humanitarian Affairs (now Office for the Coordination of Humanitarian Affairs) in 1991.

Yet, from another perspective, the Decade is also an example of how a global observance may be used by different actors as a projection screen for a variety of different agendas. Japan, for instance, had a vested interest in decreasing the effects of "natural" disasters as an exposed country and also wanted to raise its profile at the UN. France used the Decade to promote the droit d'ingérence. The UN Secretariat also formulated its own understanding of the Decade, and as soon as the Decade was launched under its leadership, Press and his network not only lost influence over decisions relating to staffing, but also, to a certain extent, over its orientation. The name-change of the Decade from "hazard reduction" to "disaster reduction" alone announced a widening of the scope from a purely technical and scientific to a more inclusive understanding of the problem. Natural disaster reduction was not only increasingly linked with other issues high on the UN agenda, such as sustainable development and environmental concerns, but also with non-technological solutions that would incorporate ideas about social vulnerability. Although this episode can thus be seen as an exceptional example of how an epistemic community formed around an influential scientific figure to push for an international framework to address disaster risk, it also shows, again, the limits of the coherence and influence of this community. 